\begin{tabular}{|c|c|}
\hline Title & Вступительные замечания \\
\hline Citation & 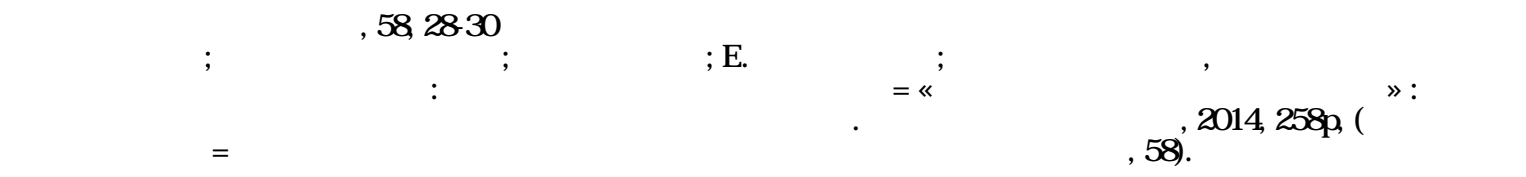 \\
\hline Issue Date & $2014-03-25$ \\
\hline Doc URL & http://hdl.handle.net/2115/56221 \\
\hline Type & report \\
\hline File Information & 18remarks_ru.pdf \\
\hline
\end{tabular}

Instructions for use 


\section{Вступительные замечания}

\section{Структура книги}

- $\mathrm{B}$ «Тексте ниңма̄ I (обозначение на латинице/перевод на японский)» в рамке слева первоначальный текст на уйльтинском языке (на латинице), справа его перевод на японский язык, в соответствии с его последовательным номером.

- $\mathrm{B}$ «Тексте ниңма̄ II (обозначение на кириллице/перевод на русский)» в рамке слева первоначальный текст на уйльтинском языке (на кириллице), справа его перевод на русский язык, в соответствии с его последовательным номером (который аналогичен номеру, указанному выше).

\section{Оригинальный текст на уйльтинском языке}

- В настоящей книге используется фонетическое обозначение на латинице, основанное на Икегами (1997), и фонетическое обозначение на кириллице основанное на Икегами и др. (2008). Фонетическое обозначение на кириллице, соответствующее фонетическому обозначению $\mathrm{n}$ на латинице, обозначается как $\mathrm{f}$, однако для типографического удобства в этой книге заменено на л.

Гласные: а/ a, ә/ э, о/ о, ө/ $ө$, u/ y, i/ и, е/ е

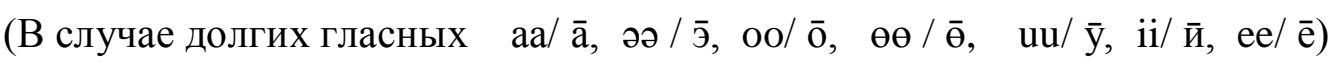

Согласные: p/ п, b/ б, t/ т, d/ д, с̌/ ч, $\mathrm{n} / \mathrm{n}, \quad \mathrm{y} / \mathrm{y}, \quad \mathrm{l} /$ л, $\mathrm{r} / \mathrm{p}, \quad \mathrm{s} / \mathrm{c}, \quad \mathrm{x} / \mathrm{x}, \quad \mathrm{w} / \mathrm{B}, \quad \mathrm{j} / \mathrm{j}$

- Фонетическое обозначение на латинице и кириллице первоначального текста на уйльтинском языке находятся в отношениях соответствия (аналогии), описанных выше, за исключением наличия нижеупомятого символа [ ]. За основу берется текст с фонетическим обозначением, написанный от руки в тетрадях профессора Икегами (далее - тетради Икегами), а также, была добавлена одна часть, откорректированная Бибиковой после еe прослушивания записи. 
- В начале предложений и в именах собственных заглавные буквы не используются.

- Припевы, которые являются репликами действующих лиц, в отличии от декламации в фоновом тексте, выделяются жирным шрифтом.

- В первоначальном тексте на уйльтинском языке «Текста ниума̄ I (обозначение на латинице/перевод на японский)» звуки, не встречающиеся в обычном произношении, но которые добавляются при пении (к примеру, добавление в начале слова перед гласным звуком фонемы «н» (n) или на конец слова добавляется фонема «и» (i) и т. д.), будут взяты в квадратные скобки [ ]. Выбор надлежащих фонем был произведен в соответствии с толкованием Бибиковой. Однако, в «Тексте ниңма̄ II (обозначение на кириллице/перевод на русский)», согласно линии Бибиковой, обозначение данных фонем было опушено (за исключением гласных, произносимых с протягиванием).

- Слова gəə/ гэ в песенной части, которые добавлены после цитирования gunčəəゥ/ гунчэ̆н «так сказал(-а)», являются интерлюдией, вставляемой слушателем ниңма̄. Однако, так как во время записи не было слушателя, который сопровождал бы исполнение песни своими словами, то, можно предположить, что эти слова были добавлены самой Сато Чиё (мнение Бибиковой).

- Нумерация по последователности была произведена для удобства и не обязательно означает конец предложений.

· Курсивный шрифт означает паузу или ошибку.

\section{Перевод на японский и русский языки}

- Русский перевод был сделан Бибиковой, которая взяла за основу свои знания родного уйльтинского и эвенкийского языков, а также посредством изучения соответствующей литературы и расспрашивания носителей языка из своего окружения. Перевод является смысловым. Японский перевод был составлен Ямадой, которая сверяясь с русским текстом Бибиковой, также использовала записи в тетрадях Икегами. Японский перевод Ямады является дословным переводом уйльтинского текста. Часть записей из тетрадей Икегами (в частности, толкование песенного звучания на уйльтинском языке) дополнена в качестве источника (i) в приложении.

- Междометия go/ го или ga/ гэ и т. д., часто вставленные между словами, 
также как и вышеописанные пауза и ошибки, которые выделены курсивом, не переведены в обоих текстах.

\section{Диск с записью (CD)}

- Оригинал записи был сделан на магнитофонной кассете, на семи сторонах (одна сторона 45 минут). В этой связи, приложенный $\mathrm{CD}$ диск состоит из семи файлов. Продолжительность записи каждой стороны около 46-47 минут, и лишь последняя сторона (Ningmaa 7) около 10 минут, в итоге общая продолжительность примерно 4 часа 45 минут. В начале самого первого файла Ningmaa 1 голос Сато Чиё произнося: “тундадо̄ дөө анани хују бе хори нада инэуи эсинэуи. Напка" «27 сентября 52 года (сёва), сегодня, Напка», говорит дату и свое имя. Обозначение содержания файлов в последовательной нумерации в основном тексте будет выглядеть следующим образом:

Ningmaa 1: 001-168

Ningmaa 2: 169-348

Ningmaa 3: 349-473

Ningmaa 4: 474-642

Ningmaa 5: 643-784

Ningmaa 6: 785-962

Ningmaa 7: 963-996

• Формат файла - MP3, который проигрывается на компьютере или CD-плеере, поддерживающим данный формат.

* Репродукция, обработка, рециркуляция и опубликование на веб-сайтах в интернете данного CD без разрешения запрещены. 